\title{
O LETRAMENTO LITERÁRIO ATRAVÉS DE NARRATIVAS DE JOSÉ J. VEIGA
}

Fabianna Simão Bellizzi Carneiro*

RESUMO: Das várias concepções de se analisar o processo do letramento literário, não podemos abdicar da concepção que, indubitavelmente, formará o verdadeiro leitor: prática social da leitura literária que compreende não apenas fruição e prazer estético, bem como posicionamento crítico diante da leitura da obra. O propósito deste trabalho é tornar patente algumas considerações acerca da literatura fantástica, e como esta pode fornecer importantes contribuições à formação do leitor literário, uma vez que temas recorrentes nesta vertente literária como morte, medo, aparições fantasmagóricas, dizem a respeito, muitas vezes, de nossas inserções no mundo que nos rodeia, nossas inquietações diante da vida, além de nossa transitoriedade e finitude, contribuindo, assim, para instigar o referido posicionamento crítico que a leitura pode proporcionar. Nosso corpus de análise traz os contos: "Fronteira", "A Invernada do Sossego" e "Os do outro lado", do escritor goiano José J. Veiga (1915-1999), publicados inicialmente em 1959 na coletânea Os cavalinhos de Platiplanto. Tais narrativas contextualizam, através do fantástico, importantes assuntos como ritos de passagem, amadurecimento infantil e solidão. Trata-se de um trabalho não conclusivo, cuja metodologia se pauta em pesquisa bibliográfica que será devidamente referenciada ao longo do texto.

PALAVRAS-CHAVE: Letramento literário; Literatura brasileira; Literatura fantástica.

\section{Notas introdutórias}

Em Alfabetização e linguística, o autor Luiz Carlos Cagliari (2009, p. 130) avulta que: "A leitura é uma herança maior do que qualquer diploma".

Aquilatamos de grande importância tal assertiva, uma vez que em contato com a leitura o leitor tem mais condições de conquistar uma posição de sujeito, de guiar sua própria história e não apenas ser objeto das veleidades ou discursos alheios, afinal, em tempos

\footnotetext{
* Professora Adjunta da Universidade Federal de Goiás (UFG). Doutora em Estudos Literários pelo Programa de Pós-Graduação em Letras da Universidade do Estado do Rio de Janeiro (Ueri). Integra o grupo de pesquisa Mundos possíveis do insólito ficcional.
} 
de crise (cultural, econômica, política, social), atrevo-me a defender que a leitura literária (e as artes de uma forma geral) pode propiciar a reconstrução de si (PETIT, 2012), bem como propiciar um exercício psíquico salutar e engajado. Afinal, que mundo teríamos se não pudéssemos dar vazão às nossas emoções, medos, alegrias ou temores? Destarte, muitas pessoas encontram, nas artes, um caminho para simbolizar e exteriorizar emoções intensas, conflitos reprimidos ou situações traumáticas. Enfim, construir um sentido para suas existências, conforme a própria mitologia e a tradição oral já nos mostravam.

$\mathrm{Na}$ contemporaneidade - era digitalizada e altamente conectada, em que o "valor de troca" mede-se pela pressa e pelo individualismo, desarticula-se a oralidade, o "olho no olho" e o contar e recontar de histórias e narrativas. Nesse momento, a leitura soa, muitas vezes, como "distração" e preenchimento curricular nas escolas, ou artefato cultural das elites. Não estaríamos, então, nos esquecemos de nossa história de exploração e colonização, quando os primeiros colonos em terras brasileiras tomaram como imediatas providências nosso apagamento cultural e linguístico de forma a dominarem as populações nativas? Para além da distração e do prazer estético, a leitura literária pode nos fornecer posicionamento crítico, a percepção do outro e o conhecimento da experiência humana em sua plenitude, e aqui recorto a vertente literária fantástica.

Veremos, ao longo deste trabalho, que a literatura fantástica convoca, através de um enredo, personagens, cenários e situações distorcidas do real empírico, a narração de nossa própria história, ainda que simbolizada através de fadas, duendes, monstros ou bruxas. O que temos, nessas narrativas, é a nossa história tecida através de episódios inauditos, porém que dizem a respeito de nossas sociedades.

Não se trata de catalogar os infortúnios humanos ou nomear nossos medos elencando narrativas que tratam da morte, solidão ou aparições fantasmagóricas. Trata-se, no entanto, de defender um tipo de escrita (nem sempre aceita pela crítica ou então tida para crianças ou iniciantes), subjetivamente rica, que penetra as vastas zonas do desconhecido e que nos leva à compreensão de nosso mundo e nossas relações cotidianas e reais - estas 
muitas vezes insólitas e desfocadas, como as guerras, os preconceitos, a violência e a fobia do Outro: a verdadeira irrealidade que nos assombra.

Não busco, neste trabalho, o ineditismo. Por outro lado, acredito que enquanto profissionais de Letras devemos perpetuar o incansável trabalho de se reforçar a importância da literatura, e em especial do letramento literário.

\section{Alfabetização, letramento e letramento literário: breves conceitos}

Até as últimas décadas do século XX, no Brasil, utilizavam-se práticas de ensino da escrita e leitura que desconsideravam não apenas as demandas sociais do aluno, bem como o próprio contexto social de fala, ou seja, tais práticas não se relacionavam com a oralidade e com linguagens não-verbais, por exemplo. Mais ainda: essas práticas enfatizavam o processo de ensino, ao passo que o processo de aprendizagem ficava relegado a um patamar secundário: a alfabetização se concretizava, exclusivamente, em eventos situados dentro da sala de aula e mediados por um especialista (o professor) encarregado de ensinar, de forma sistematizada e coletiva, as regras do "bom funcionamento" e uso do código alfabético. Nesse momento, um aluno alfabetizado era aquele que dominava o código alfabético para exercer a arte e ciência da escrita (RIBEIRO, 2003).

Nesse tipo de ensino não caberia fornecer letras às crianças de forma a fazer com que elas se mobilizassem às práticas de leitura em outras esferas de atividade, que não exclusivamente as escolares. Isso, em parte, explica um pouco da confusão que muitos fazem com os conceitos de alfabetização e letramento, como se fossem excludentes ou separados, quando de fato a alfabetização (em qualquer de seus sentidos), é inseparável do letramento. Ela é necessária para que alguém seja considerado plenamente letrado, mas não é o suficiente (KLEIMAN, 2005, p. 14). Em outras palavras, pessoas que não possuem domínio do alfabeto não podem ser consideradas pessoas "iletradas", uma vez que participam, ainda que de forma marginal, das práticas letradas de sua comunidade: "Enquanto a alfabetização se ocupa da aquisição da escrita por um indivíduo, ou grupo de indivíduos, o letramento 
focaliza os aspectos sócio-históricos da aquisição de uma sociedade" (TFOUNI, 1995, p. 20).

Não discuto, obviamente, a alfabetização como algo aquém do letramento ou que ela impossibilite a adequada absorção do letramento. Reforço que não são excludentes, mas não deixo de olhar para um interessante processo que se inicia nas últimas décadas do século XX, quando ao processo de alfabetização adicionam-se questões de ordem social, cultural, prática e até mesmo de ordem tecnológica. Foi no contexto das grandes transformações culturais, sociais, políticas, econômicas e tecnológicas que o termo "letramento" surgiu, ampliando o sentido do que tradicionalmente se conhecia por alfabetização (SOARES, 1998).

Momento em que estudiosos da educação defendem que o uso da língua escrita não apenas se transforma ao longo do tempo, como não pode ficar restrito ao domínio de uns poucos, devendo se tornar um direito de todos: "Há cem anos, para ser alfabetizado era suficiente ter domínio do código alfabético, mas hoje se espera que, além de dominar esse código, o aluno consiga se comunicar, por meio da escrita, numa variada gama de situações” (KLEIMAN, 2005, p. 21). Daí que o termo letramento passa a ser utilizado como reflexo das transformações tanto dentro como fora das escolas, não deixando de incluir as práticas escolares de uso da escrita, porém ampliando-as, ou seja, trazendo aspectos sociais e históricos dos usos da escrita para a sala de aula e para o processo de alfabetização. Alinho-me com as observações de Rildo Cosson (2015, p. 175) quando o autor assinala que

conceito de letramento expressa, por um lado, uma nova compreensão da leitura e da escrita e das relações entre saberes e educação, e por outro, faz parte de um contexto, onde se postula um ensino por competências, as tecnologias de informação e comunicação se tornam mais acessíveis, o fluxo de informações se mundializa, as imagens adquirem status de texto, as práticas de autosserviço se tornam cotidianos e o acesso ao ensino superior chega a camadas menos favorecidas da sociedade, isso só para falar de alguns dos tópicos que fazem parte do horizonte do letramento mediático, letramento financeiro, letramento crítico, letramento em saúde, letramento visual, informacional, científico, acadêmico, para citar alguns dos adjetivos que acompanham o termo letramento. 
Ao observarmos nossas situações cotidianas podemos entender que para termos pessoas plenamente letradas, não há como dissociarmos alfabetização e letramento. A alfabetização nos mobiliza a decifrarmos os códigos escritos ao passo que o letramento nos permite destrinchar tais códigos de forma que possamos entrar em camadas mais profundas do texto escrito. Trata-se de um processo complexo, que envolve muito mais que um conjunto de habilidades ou uma competência de leitura. Estamos falando de habilidades e competências que permitem à uma pessoa inserir-se em sociedade e participar das práticas sociais ali presentes. E aqui podemos falar, seguramente, da importância do letramento literário como uma dessas competências que perfazem a prática do letramento.

Concomitante ao fato de o processo de alfabetização, no Brasil, ter priorizado, em alguns momentos, o ensino em detrimento da aprendizagem, algo semelhante (guardadas as devidas especificidades) ocorreu com o ensino de literatura em nosso país, e o fato de termos sido colônia europeia em parte corroborou para tal. Durante algum tempo o ensino de literatura esteve atrelado ao ensino do cânone português, sendo que a leitura de obras clássicas da literatura portuguesa apenas subsidiava as aulas de retórica e latim. Posteriormente, o ensino de literatura assumiu outra característica marcante: transmissão de regras e princípios que deveriam nortear a vida dos cidadãos, principalmente por volta do século $\mathrm{XIX}$, quando os valores burgueses ditavam as regras sociais. O século XX viu ascender um tipo de ensino tão controverso quanto o dos séculos anteriores, e ainda mais pernicioso, quando o texto literário torna-se um aporte para o ensino de gramática, e quando o ensino de literatura dá-se através de cronologia e escolas literárias. Muito embora a ação dos PCN's tenha se voltado para essa questão, percebemos que há um longo caminho a ser percorrido, pois o que vemos hoje é um tipo de ensino ainda subestimado, uma vez que as práticas de trabalho com a literatura tomam o texto literário como mais um dentre a diversidade de gêneros textuais que circulam socialmente.

Exatamente esse tipo de ensino oblitera o que se preconiza como letramento literário. Os estudos literários nos mostram que o discurso literário tem suas peculiaridades e que a especificidade da literatura deve ser respeitada nas escolas, em prol de uma formação 
humana crítica, que permita ao sujeito caminhar rumo à emancipação intelectual e social. Ao trabalharmos, de fato, a essência do letramento literário, enfatizamos as práticas sociais dos leitores em contraste com uma visão enrijecida do ensino de literatura nas escolas. Essa postura docente permitirá a promoção e manutenção da leitura literária para além do espaço escolar, permitindo ao leitor uma experiência única de interação verbal. Muito embora a escola seja uma das primeiras promovedoras do letramento literário, este não pode se restringir ao campo escolar, como também não pode se limitar à escrita, pois esta é apenas um dos caminhos pelos quais a linguagem literária se presentifica. Sob este viés, o letramento literário seria um processo de aprendizagem, “[...] resultado da experiência do leitor com o texto, simultaneamente solitário e solidário porque implica negociar, reformar, construir, transformar e transmitir o repertório que recebemos de nossa comunidade como literário” (COSSON, 2015, p. 183).

Em nossas práticas diárias enquanto profissionais das Letras, vemo-nos diante de um cenário cáustico, em que o ensino de literatura nas escolas mostra-se claudicante. Ao atravessarmos os muros escolares, a leitura literária digladia-se com o acirrado processo de informatização, em que se verifica o surgimento de um mundo instável, reconfigurado pela pressa, pelos suportes eletrônicos e digitais, e por uma intensa movimentação do cotidiano das pessoas. Mundo marcado pelo acelerado movimento de informações, pelo centramento no individual, em detrimento dos interesses coletivos, e mobilizado pelo consumo (LYOTARD, 1986).

Não me cabe, neste trabalho, cotejar um discurso pedagógico onde se avulta a importância do letramento literário na escola, mas devo considerar que é no espaço escolar que o docente deve levantar importantes questões que solidificarão o letramento literário e formarão o leitor solidário, o leitor verdadeiramente consciente de sua inserção em um mundo prenhe de incertezas e danificado em sua relação com o outro - uma relação distante e mediada por inúmeros aparatos tecnológicos. Nesse contexto instável, o docente 
deve carregar consigo questões como: Por que ensinar Literatura? Qual é o lugar da Literatura na escola? Por que ensinar Literatura se seu estudo não se coaduna com a proposta desse mundo virtualizado e tecnológico?

Sabemos que o lugar da literatura, na escola, é um lugar, muitas vezes, instável e permeado por tensões. Atualmente, “[...] a escola parece prescindir da literatura [...]” (ZILBERMAN, 2009, p. 09), ficando a cargo do professor - impulsionado, muitas vezes, por seus gostos pessoais - enfatizá-la, considerando suas especificidades e funções, ou negligenciá-la, parcial ou totalmente, diluindo-a em meio à diversidade de gêneros textuais trabalhados ou substituindo-a por resumos, paráfrases e simulacros. Conforme Zilberman (2009, p. 18) aponta, para que a literatura ocupe lugar de destaque na escola, faz-se necessário encontrar ou o sentido de sua permanência no currículo, ou outra formatação de escola, que esteja aberta para acolher a arte literária, dando-lhe seu devido valor e promovendo o que se pode considerar como verdadeiro letramento literário, a saber: uma competência a ser desenvolvida em um nível que ultrapassa a associação da literatura com a aprendizagem escolar. Que não ensine "sobre” literatura, mas que promova uma verdadeira imersão no texto literário de forma a fazer com que o leitor consiga (ainda que em um primeiro momento pelas mãos do docente, e posteriormente sozinho), sair da superficialidade do texto literário e desvendar a beleza do "não-dito". Vários gêneros textuais possibilitam isso, é certo. Podemos, inclusive, falar em letramentos, mas por ora defenderemos o letramento literário como importante agente na formação do leitor, não apenas pelo caráter humanizador da literatura (CANDIDO, 1995) e por favorecer a descoberta de si e do outro, quanto pelo fato de promover a reinvenção de sentidos pela força da palavra:

É justamente por ir além da simples leitura que o letramento literário é fundamental no processo educativo. $\mathrm{Na}$ escola, a leitura literária tem a função de nos ajudar a ler melhor, não apenas porque possibilita a criação do hábito de leitura ou porque seja prazerosa, mas sim, e, sobretudo, porque nos fornece, como nenhum outro tipo de leitura faz, os instrumentos necessários para conhecer e articular com proficiência o mundo feito linguagem. (COSSON, 2007, p. 30) 
Sabemos que não há um modelo correto e que não se trata de adotar determinada concepção, mas podemos (e devemos) tornar o termo mais factível para todos os usuários, e aqui entendemos usuários como aqueles que letram, os que são letrados e por fim as pessoas que carregarão o letramento (ou letramentos) para suas inserções sociais, de forma que possam desenvolver o real pensamento crítico.

Diante dessa miríade de possibilidades, seleciono o letramento literário que pode se dar através da literatura fantástica como importante função a possibilitar o pensamento crítico, conforme veremos a seguir.

\section{O letramento literário através da literatura fantástica de José J. Veiga}

No prefácio do livro Por que estudar literatura (2012), Vincent Jouve elenca oportunos questionamentos: estudar literatura ampliaria nosso universo cultural, muito embora o próprio autor contraponha outros sistemas semióticos como importantes ao nosso arcabouço cultural, como música, pintura, escultura. Sem cair em ciladas ou esquemas apriorísticos, Jouve enfatiza, ao longo de seu trabalho, que por se tratar de um tipo de linguagem particularizada, e que ainda possui estatuto de objeto de arte e estética, não podemos perguntar por que estudar literatura (e aqui seria inútil defendê-la como a arte mais importante), uma vez que estaríamos levantando um questionamento sem resposta: o paradoxo da arte que, “[...] embora não tendo utilidade prática, toca dimensões da existência tão fundamentais quanto a cultura, a educação ou a comunicação (JOUVE, 2012, p. 11).

Possuidora de uma linguagem específica, a beleza da literatura reside no fato (e aqui vários artefatos culturais promovem isso) de que o confronto entre a tessitura ficcional e os nossos elementos empíricos, enriquece nossa existência. Aqui podemos defender que a literatura promove esse movimento de forma mais esgarçada, uma vez que nos relacionamos com o texto nos planos sincrônico "[...] o texto é portador de saberes que estruturam nossas representações e diacrônico (o texto se inscreve em um legado, que ele transmite e reavalia)" (JOUVE, 2012, p. 163), e isso faz com que proliferem vetores a favor do senso crítico e a partir de um trabalho livre, ativo e dinâmico por parte do leitor. Ao se 
distanciar de suas ideias, valores e visão de mundo e contrapô-los ao texto literário, o leitor caminha em direção ao que discutimos até o momento: o letramento literário.

Dentro do campo de estudos da teoria literária, faço um recorte nas teorias que versam sobre o fantástico e vejo que todas, embora por vieses diferentes de acordo com a época, com o estatuto social ou até mesmo com o país de origem, convergem quando nos mostram que a vertente fantástica expõe a condição humana, porém carregada de nuances que fogem à realidade empírica, ou seja, quer trabalhada nos contos de fada, nas narrativas góticas, no realismo maravilhoso, o que temos são textos que falam de nossa existência: transitória, finita e limitada, e aqui pontuamos as narrativas do escritor José J. Veiga.

Veiga retratou o interior do Brasil ressaltando a dura realidade e aspereza de pessoas que se viam oprimidas entre o progresso e as relações de trabalho no campo - relações que historicamente sempre foram confusas e legalmente irregulares. O autor também construiu personagens e situações que mostram as dores pelas quais todos vivenciam em certos ritos de passagem, independente da inserção em ambiente rural ou urbano: a morte, o desamparo dos órfãos, a falta de perspectivas com a entrada na vida adulta, a enfermidade na velhice, crianças que se responsabilizam pelo sustento da família, enfim. Agostinho Potenciano de Souza (1990, p. 21) observa, em relação aos temas que circundam a obra veigueana, que:

A seleção de temas é marcada por uma vivência pessoal, enriquecida desde o lirismo da infância até às mágoas provocadas pelos sistemas de poder tirano. Esse universo conturbado e, paradoxalmente, lírico é feito por uma linguagem próxima do falar cotidiano. Por uma elaboração cuidadosa, J. Veiga transporta seus leitores a universos estranhos e familiares, ora como quem recorda um menino e suas peripécias de "dor de infância", ora como um quase adolescente que começa a entender os interditos do mundo administrado, ora como uma voz-quase-câmera a mostrar um filme de desmandos que já vimos.

Nas narrativas de Veiga, a manifestação do fantástico se dá através da vertente do realismo mágico, em que o mundo empírico é retratado de forma opaca, quase "desfocada", ou seja, fatos insólitos e irreais são utilizados como pano de fundo de forma a revelar ao 
leitor temas profundos e inquietantes. $\mathrm{Na}$ escrita veigueana temos um legado literário do qual sobressai um texto que não deixa de trazer temas inerentes à nossa realidade:

embora apresentado de uma forma diferente, o mundo representado em sua ficção é o nosso mundo mesmo [...].

O fantástico de Veiga são as situações dolorosas [...] contrárias à razão - e o registro de como o ser humano é capaz de resistir a elas, mesmo quando essa resistência o leve a situações vivenciais insuportáveis. Sob esse ponto de vista, as histórias de Veiga não são narrativas fantásticas [...] ele se utiliza do fantástico apenas como recurso - o exagero da verdade -, para que o realismo possa emergir (AMÂNCIO, 1982, p. 101).

Veiga consegue problematizar a realidade, ainda que de forma inaudita, para que não nos esqueçamos de nossa finitude e pequenez. Ainda que não seja nosso intuito, neste trabalho, destrincharmos as molduras do realismo mágico, podemos, de uma forma asinha, destacar que se trata de uma escrita que brota entre as décadas de 40 e 50 do século XX e que explica a passagem da estética realista-naturalista para uma visão mágica da realidade. Tal estética fora consagrada por escritores hispano-americanos como uma forma de referenciarem a dura realidade social, a problemática do subdesenvolvimento e as escabrosidades dos regimes ditatoriais, porém enoveladas pela "magia” (CHIAMPI, 2008, p. 19-23), o que não quer dizer que a literatura fantástica deva se situar ao polo oposto da realidade. $\mathrm{O}$ que notamos, especificamente no realismo mágico, são narrativas em que ocorre a irrupção de elementos insólitos de forma naturalizada, porém não deixam de ser críveis ou não deixam de apontar para a mais dura e cruel realidade, o que fica bastante evidente no conto "A invernada do sossego" (1986).

Nesse conto temos a presença de um narrador-personagem que traz uma história de amor e lealdade entre um cavalo, de nome Balão, e dois irmãos. Um dos irmãos é o próprio narrador, que sem nome revelado, relata o desespero e a tristeza após encontrar seu cavalo morto. Inconformados, resolvem agir como se o cavalo estivesse vivo. Somamos, ao acordo entre os irmãos, a própria postura do leitor, que ao compactuar com a 
realidade onírica e distorcida, revelada através de um sonho, não questiona a irrealidade presente em um espaço mais livre, solto e utópico:

[...] já íamos longe, em terras muito distantes das nossas, uma várzea de buritis a perder de vista. De vez em quando o Balão entortava o pescoço pra trás, acho que para verificar se estávamos contentes, depois resfolegava feliz, empinava a crina e seguia em passo ganjento. Que terras seriam aquelas? (VEIGA, 1986, p. 90)

Essa mudança de espaço, do corriqueiro para o encantado e para o devaneio (SOUZA, 1990, p. 102), permite aos meninos reviverem os bons momentos que tiveram com Balão, quando o cavalo ainda era vivo. Importante destacar que nesse espaço mágico, não se fala em morte ou cavalo que havia ressuscitado. Os meninos simplesmente vivem aquela situação de forma corriqueira, sem se preocuparem em buscar explicações para o inaudito que se instalara. O inaudito, inclusive, é algo muito próprio do mundo infantil. As crianças passeiam com bastante desenvoltura pelo terreno da imaginação e fantasia, e conforme amadurecem deixam vários personagens por elas criados naquele primeiro estágio de suas vidas: "A paixão pela fantasia começa muito cedo, não existe infância sem ela, e a fantasia se alimenta da ficção, portanto não existe infância sem ficção” (CORSO e CORSO, 2006, p. 21).

No conto em análise, o local da Invernada perfaz um espaço no qual os meninos podiam dar vazão aos seus sonhos e crenças: “(...) a Invernada do Sossego existia, qualquer pessoa podia ir lá se não ficasse aflito para chegar.” (VEIGA, 1986, p. 91). Neste espaço, as crianças vivenciavam a fase infantil, sem as preocupações que tinham com o trabalho da roça. Porém, há um contraponto a esse espaço (onde os meninos retêm Balão vivo na memória): a presença dos Capadócios. Alertados por Zeno, garoto que também frequentava a Invernada e que brincava com Balão, os irmãos recebem a notícia de que os Capadócios eram perigosos e matavam cavalos:

- Você não tem cavalo não, Zeno?

Zeno empurrou a cabeça de Balão para um lado e respondeu: 
— Não pense que estou querendo tomar o seu cavalo. Aqui é assim. Os cavalos daqui não têm dono porque são de todos.

— E não tem briga? - perguntei.

- Com gente daqui, não. Quem briga são os Capadócios, que aparecem de repente armados de garrucha e fazem um estrago medonho.

- Eles não gostam de cavalo? — perguntou Benício.

- Gostam muito, mas é para matar.

- E vocês que vivem aqui, por que deixam?

— Vontade de correr com eles não falta, mas ninguém aguenta. Não se pode nem chegar perto, fedem muito.

— Nem tapando o nariz? (VEIGA, 1986, p. 92)

Com a chegada dos Capadócios, os irmãos decidem se esconder, junto com Balão, em um buraco cavado na terra. Por conta da confusão de cavalos correndo sem direção, um dos Capadócios cai no buraco e em cima do narrador:

Fiz o Pelo-Sinal e armei o pulo para sair, mas quem diz que eu conseguia levantar o corpo? Um peso impossível segurava-me no fundo do buraco, Que poderia ser? Algum cavalo morto? Fechando os olhos para não ver, fui apalpando devagar aquele corpo quente que pesava em cima de mim e concluí que não podia ser cavalo. Cheirei a mão com medo - e compreendi. Os Capadócios pesam mais do que chumbo, era inútil tentar escapulir. (VEIGA, 1986, p. 93)

Embora a ameaça dos Capadócios também faça parte do espaço do fantástico da Invernada do Sossego, há muito que se dizer a respeito destes seres que cheiram mal. Assim como os Capadócios que retiraram dos meninos um animal muito querido, a morte vem a nós de forma inexorável e nos retira pessoas e momentos agradáveis. Com um odor insuportável, que nos remete ao odor dos corpos em decomposição, os Capadócios alegorizam a morte, que chega a qualquer momento e sem dar aviso.

Se no conto “A Invernada do Sossego" reproduz-se, através da vertente fantástica, o primeiro choque da realidade da vida presenciada por crianças, como a morte, no pequeno conto "Fronteira", uma criança passa pelo doloroso rito de passagem entre a infância e a idade adulta. 
Muito mais existencial que conceitual, o fantástico, em "Fronteira", está ligado às sensações de estranhamento e incômodo do personagem, um garoto que se sente como se estivesse no alto de uma montanha a decidir entre descer ou não, o que na verdade alegoriza o seu próprio amadurecimento. $O$ narrador, também criança, inicia sua fala elencando personagens emoldurados por estranhamento e encanto, mas que simbolizam os obstáculos e intempéries de nossas vidas:

Eu era ainda muito criança, mas sabia uma infinidade de coisas que os adultos ignoravam. Sabia que não se deve responder aos cumprimentos dos glimerinos, aquela raça de anões que a gente encontra quando menos espera e que fazem tudo para nos distrair de nossa missão; sabia que nos lugares onde a mãe-do-ouro aparece à flor da terra não se deve abaixar nem para apertar os cordões dos sapatos, a cobiça está em toda parte e morde manso; sabia que ao ouvir passos atrás ninguém deve parar nem correr, mas manter a marcha normal, quem mostrar sinais de medo estará perdido na estrada. (VEIGA, 1986, p. 61)

No conto, a hesitação e inquietação são provocadas pelo enigma do acontecimento, ou melhor, pela incerteza do que virá pela frente. É dessa forma que o menino, narrador consciente, passa pelos episódios da história, se perguntando o que está acontecendo ou por que está acontecendo. Tomados pelos acontecimentos, os narradores veigueanos reproduzem a proposta de Retinguer (1974, p. 10 apud SOUZA, 1990, p. 44), '[...] para diferenciar o conto fantástico do conto de fada: a luta do ser revoltado e aliado aos poderes inferiores contra os poderes superiores", e no caso do conto "Fronteira", evidencia-se o poder inferior do garoto frente à vida que avança:

O fantástico não é o absurdo existencial, se permanecer no plano dos fatos extraordinários. É necessário tornar-se um clima, uma diferença do comum, uma inquietação contínua.

A voz narrativa veigueana conduz a uma leitura que transcende os simples fatos insólitos, pois a atmosfera toda dos romances é que determina uma porosidade aberta ao domínio do fantástico. (SOUZA, 1990, p. 37) 
Tanto em "A Invernada do Sossego" quanto em "Fronteira", alinha-se o fantástico nas estranhezas que massacram e oprimem personagens e contextos, o que na verdade acaba por reproduzir os processos naturais da vida, que muitas vezes nos oprimem e entristecem: crescimento, morte e ritos de passagem.

No conto "Os do outro lado", no entanto, o efeito de estranhamento advém perante situações do devir. O enredo é simples. De forma resumida, temos uma criança que recebe a incumbência de transportar um prato de jabuticabas, respeitando a condição de não ultrapassar o outro lado da cidade. Certo dia depara-se com uma misteriosa casa vermelha. Depois disso, são narradas algumas de suas desventuras até a hora em que retorna à casa escarlate e presencia a manifestação do insólito: pessoas flutuando no ar.

Mais uma vez a história é conduzida pela voz de uma criança, que relata os acontecimentos extraordinários por ela vivenciados e as agruras pelas quais passam os moradores de uma pequena cidade do interior, e aqui ressaltamos os elementos comumente presentes nas narrativas de Veiga: o lugar de fala da criança, os cenários regionalistas, e a irrupção de fatos insólitos como se fossem práxis locais. Especialmente em "Os do outro lado", apesar de descabida tal proibição, não há questionamento algum por parte dos moradores. Fato semelhante parece ocorrer com a atitude do leitor que também não questiona as irrupções insólitas, e aqui destaca-se a construção do enredo, cuja coerência interna legitima o inaudito, o que acaba por comprometer o leitor com o estatuto de credibilidade:

Um dos modos veigueanos mais singulares é o das passagens de um plano para outro, do corriqueiro para o plano do insólito. É nessa translação que J. Veiga tem seu jeito próprio de instaurar o curso do fantástico que nos remete à mesma lógica narrativa, apresentando cada elemento como o inverso exato de um outro, convergindo os diversos planos do real, por meio de um deslocamento que não é troca ou fuga, e sim, desenvolvimento, retomada. (FIGUEIREDO, 1984, p. 60 apud SOUZA, 1990, p. 33)

Em outros termos, a lógica fantástica apresentada por Veiga utiliza-se de importantes recursos como aproximação do leitor com a cena e presença do narrador em primeira 
pessoa, aproximando, assim, narrador, enredo e leitor e persuadindo este a adentrar o universo ambíguo do insólito. Tal se insinua logo nas primeiras linhas do conto, quando o narrador apresenta um fato inquietante, ou seja, deparar-se com uma enorme casa vermelha, desconhecida para ele, apesar de localizada em um espaço familiar:

A casa era grande e alta, de tijolos vermelhos, talvez a mais alta do lugar. Ficava atrás de uma cerca de taquara coberta de melões-desão-caetano. Mas sendo tão grande, tão alta e de cor tão viva, e a cerca não tendo mais que a altura de um homem médio, nunca pude compreender por que não era vista da rua. Desde que me entendo, eu passava por lá todos os dias, para cima e para baixo, lembro-me bem da cerca inclinada aqui e ali ao peso da folhagem [...]. Lembrome de tudo isso mas não me lembro da casa vermelha anteriormente aos acontecimentos que vou relatar. (VEIGA, 1986, p. 51)

Muito embora não haja uma demarcação óbvia do inaudito, uma vez que ele se encontra amalgamado a outros elementos miméticos do texto, em “Os do outro lado" o que temos é uma instauração gradativa do sobrenatural mesclada à presença do verossímel, e que nos leva ao mundo empírico, ou seja, ainda que o leitor possa se questionar a respeito de uma casa incomum ter permanecido invisível a um menino, e que em um primeiro momento ficava no lado proibido, ou do outro lado, a manifestação do insólito, de forma gradual, atenua tal questionamento.

Também significativo é o fato de que a entrada do menino na casa acontece após dificuldades e superação de obstáculos: "Vejo-me transportando o prato com muito cuidado porque estava cheio de derramar, a caminhada era difícil por causa das falhas do calçamento, das ladeiras a subir e descer e eu não podia deixar cair uma jabuticaba que fosse" (VEIGA, 1995, p. 52). Carregando um prato de jabuticabas com uma acirrada responsabilidade de não derrubar nenhuma, o garoto sofre em seu caminho, o que na verdade simboliza a própria descoberta da adolescência e a difícil inserção no mundo adulto, fazendo-nos retomar os ritos de passagem já discutidos neste trabalho. Porém, esse ainda não é o fio temático da obra: após entrar na casa o menino perscruta vários espaços, aparentemente simplórios. Ao atravessar cercas, abrir portas e percorrer cômodos, a narrativa 
nos faz pensar a respeito de atividades próprias do ser humano de perscrutar realidades subjacentes à aparente e, assim, chegar a descobertas relevantes e próprias de seu processo questionador.

Uma vez transposta a cerca que envolve a casa, o insólito impregna toda a narrativa quando o menino vê pessoas familiares carregadas em enormes bolhas, que não estavam tristes:

Deu-me pena vê-los prisioneiros daquelas bolhas, sendo levados para um lugar onde ninguém queria ir. Mas por que não iam tristes? Por que não reclamavam? Por que esfregavam as mãos, como se tivessem pressa de chegar? Até Benigninho, que na escola reclamava de tudo, ia risonho e contente. Quando o viu, a irmã deu um grito e apertou-me o braço com tanta força que eu tive de empurrá-la. Pode ser impressão, mas acho que Benigno percebeu o susto da irmã, pois olhou-nos, com um sorriso tão convincente que ela mudou logo a fisionomia. (VEIGA, 1995, p. 59)

Por fim, a narrativa encontra-se com a metáfora presente no título, “Os do outro lado", pois leva o narrador à percepção mais abrangente do mundo, ainda que através de passagens insólitas, mensagens em borboletas, casas que "surgem” misteriosamente, o que na verdade metaforiza a construção de sentidos que damos à nossa existência, muitas vezes inauditos, incompreensíveis ou extraordinários.

Assim como o narrador menino, imaginamos esse plano tridimensional e descortinamos verdades da mesma forma sugeridas pela narrativa: atravessar o outro lado "Não dói! [...] - Quanto medo sem motivo! - Quanto medo sem motivo!” (VEIGA, 1995, p. 60).

\section{Considerações finais}

Nos três contos analisados notamos procedimentos narratológicos presentes em narrativas fantásticas. Em “A Invernada do Sossego", através de um discurso ficcional e metaforicamente construído e de situações insólitas, como crianças "brincando" com um cavalo que havia morrido, o inaudito sugere uma atitude que vai na contramão do que acontece em nossas sociedades individualistas. Em nossas sociedades contemporâneas, 
apressadas e digitalizadas, manter a memória de alguém que morreu, soa como algo patológico, quando, na verdade, deveria ser visto como um puro ato de afeto. Em "Os do outro lado” a presença do insólito realiza-se através de procedimentos plenos de significações: atravessar o outro lado através de passagens tridimensionais ou bolhas flutuantes, simboliza a própria descoberta do mundo ao nosso redor, ao passo que no conto "Fronteira", o próprio rito de passagem perfaz algo inaudito, uma vez que o garoto mostra toda sua estranheza e hesitação perante um processo natural, porém doloroso e marcado por sofrimento: o "vir a ser".

Os três contos trazem proximidades, ainda que por vieses diferentes: realismo mágico, estranho, maravilhoso, pois a simbologia deles advinda fala diretamente a nós, participantes das sociedades modernas e individualistas, que muitas vezes nos esquecemos ou apagamos de nossas memórias pessoas que fizeram parte de nossas vidas e de nossas relações, escondemo-nos perante as mudanças que a vida nos impõe ou nos acovardamos ao menor sinal de descobertas.

Não foi meu objetivo aprofundar-me em questões estruturais referentes à literatura fantástica, mas acredito ter alcançado meus propósitos ao reafirmar que a representação do sobrenatural, na literatura, se configura na busca de explicação e sentido para a existência, reflexo dos conflitos íntimos e anseios da humanidade em diferentes épocas. Podemos mudar o foco narrativo, podemos analisar diferentes cenários, falas, personagens, porém há algo que não muda: os textos representativos da literatura fantástica levam o leitor a imergir no subconsciente humano, construído a partir dos símbolos e metáforas que habitam as profundezas da mente. Trata-se de um movimento extremamente dificultoso e muitas vezes doloroso, e aqui sublinho que há outras opções que nos permitem tal aprofundamento, como a psicanálise, as terapias assistidas, enfim, mas acredito que as artes, e em especial a literatura fantástica, seja uma propiciadora importante desse processo não apenas pelo fato de que ela já é fornecida ao leitor em tenra idade, podendo-o acompanhar pelo resto de sua vida, mas, principalmente, pelo fato de a literatura fantástica, através de elementos estranhos e situações insólitas, conseguir falar diretamente a nós. Nosso mundo 
empírico e cotidiano, tido como "normal”, é recheado por incertezas, dúvidas e angústias, e a literatura fantástica cumpre seu papel ao comprovar que explorar ambientes sombrios e estranhos, nada mais é do que explorar nosso interior, nossa alma, e isso causa muito medo, mas é através desse encontro interior que amadurecemos e ampliamos nossa visão de mundo, bem como relativizamos o encontro mais difícil de nossa existência: o encontro com o outro.

Ao lermos, ao nos letrarmos, não apenas ampliamos nossa interpretação do texto, como ampliamos nossa interpretação de nossa sociedade. Se no início deste trabalho levantávamos alguns questionamentos a respeito do letramento literário e da literatura fantástica, agora confirmo as premissas e hipóteses iniciais ao defender que este encontro, através de dimensões alegóricas para cada texto lido, nos fornece certa carga de coerência, incongruências, contradições, afinal que mundo teríamos se não houvesse esse arcabouço de possibilidades e incoerências? Felizmente, o letramento literário possibilita uma leitura de mundo e uma releitura de nossas falsas certezas.

\section{EL LETRAMIENTO LITERARIO A TRAVÉS DE NARRATIVAS DE JOSÉ J. VEIGA}

RESUMEN: De las diversas concepciones de analizar el proceso del letramiento literario, no podemos abdicar de la concepción que, indudablemente, formará el verdadero lector: práctica social de la lectura literaria que comprende no sólo fruición y placer estético, así como posicionamiento crítico ante la lectura de la obra. El propósito de este trabajo es hacer patente algunas consideraciones acerca de la literatura fantástica, y cómo ésta puede aportar importantes contribuciones a la formación del lector literario, ya que temas recurrentes en esta vertiente literaria como muerte, miedo, apariciones fantasmagóricas, dicen al respecto, muchas veces, de nuestras inserciones en el mundo que nos rodea, nuestras inquietudes ante la vida, además de nuestra transitoriedad y finitud, contribuyendo así a instigar el referido posicionamiento crítico que la lectura puede proporcionar. Nuestro corpus de análisis trae los cuentos: "Fronteira", "A Invernada do Sossego" e "Os do outro lado", del escritor goiano José J. Veiga (1915-1999), publicados inicialmente en 1959 en la colección Os cavalinhos de Platiplanto. Tales narrativas contextualizan, a través del fantástico, importantes asuntos como ritos de paso, maduración infantil y soledad. Se trata de un trabajo no conclusivo, cuya metodología se orienta en investigación bibliográfica que será debidamente referenciada a lo largo del texto.

PALABRAS CLAVE: Letramiento literário; Literatura fantástica; Literatura brasileña. 


\section{REFERÊNCIAS}

AMÂNCIO, Moacir. J.J.Veiga. Seleção de textos, notas, estudos histórico e crítico e exercícios por Samira Youssef Campedelli. São Paulo: Abril Educação, 1982.

CAGLIARI, Luiz Carlos. Alfabetização e linguística. São Paulo: Scipione, 2009.

CANDIDO, Antonio. Vários Escritos. 3 ed. São Paulo: Duas Cidades, 1995.

CHIAMPI, Irlemar. O realismo maravilhoso: forma e ideologia no romance hispano-americano. 2. ed. São Paulo: Perspectiva, 2008.

COSSON, Rildo. Letramento Literário: teoria e prática. São Paulo: Contexto, 2007. Letramento Literário: uma localização necessária. Letras \& Letras, Uberlândia, v. 31, n. 3, p. 173-187, jul./dez. 2015. Disponível em: http://www.seer.ufu.br/index.php/letraseletras . Acesso em: 08 set. 2018.

CORSO, Diana Linchtenstein; CORSO, Mario. Fadas no divãa: psicanálise nas histórias infantis. Porto Alegre: Artmed, 2006.

JOUVE, Vincent. Por que estudar literatura? Trad. Marcos Bagno e Marcos Marcionilo. São Paulo: Parábola, 2012.

KLEIMAN, Angela B. Preciso ensinar o letramento? Não basta ensinar a ler e escrever? Campinas: Cefiel - Unicamp; MEC, 2005.

LYOTARD, Jean-François. O pós-moderno. Trad. Ricardo Correa Barbosa. Rio de Janeiro: José Olympio, 1986.

PETIT, Michèle. $A$ arte de ler ou como resistir à adversidade. Trad. Arthur Bueno e Camila Boldrini. São Paulo: Ed. 34, 2009.

RIBEIRO, V. M. (org.) Letramento no Brasil. São Paulo: Global, 2003.

SOARES, M. B. Letramento: um tema em três gêneros. Belo Horizonte, Autêntica, 1998.

SOUZA, Agostinho Potenciano de. Um olhar crítico sobre nosso tempo. Uma leitura da obra de José J. Veiga. Campinas: Editora da UNICAMP, 1990.

TFOUNI, L.V. Letramento e alfabetização. São Paulo, Cortez,1995.

VEIGA, José J. “Os do outro lado”. In: Os cavalinhos de Platiplanto: contos. São Paulo: DIFEL, 1986. p. 51-60.

. Fronteira. In: Os cavalinhos de Platiplanto: contos. São Paulo: DIFEL, 1986. p. 61-64.

A invernada do sossego. In: Os cavalinhos de Platiplanto: contos. São Paulo: DI-

FEL, 1986. p. 85-94. 
ZILBERMAN, Regina; RÖSING, Tania M. K. (Org.). Escola e Leitura: velha crise, novas alternativas. São Paulo: Global; ALB, 2009.

Recebido em: 18/08/2018.

Aprovado em: 12/01/2019. 